\title{
Cooperation Between Co-operative Business Organization and Investor Owned Firm to Stimulate Economic Growth of a Country: A Cooperative Advantage Approach
}

\author{
Chanchai Petchprapunkul \\ Kasetsart University, Bangkok, Thailand
}

\begin{abstract}
This study elaborates that the economic growth of a country depending on not only the business performance of the investor owned firms (IOFs), but also the business surplus of the cooperative organizations (Co-ops). The policy maker should have the level of understanding and competence to blend five different factors related to organizational structure and business model of the Co-ops and the IOFs to the five similarities factors on the managerial approach of them into one marked. The study investigated five similarities factors and included into a conceptual structural model with its six measurement models, economic growth model, general national factor model, market and industry factors model, Co-ops/IOFs opportunities/threat model, Co-ops/IOFs strength /weakness model, and lastly the Co-ops/IOFs firm dynamic/active: sales, profit, and lost model. Reliability of the six similarities measurement models was tested by the Delphi technique with a sample of 33 respondents. The study found that, apart from the six measurement models, it also has two intervening factor variables that will reduce the power and magnitude of the economic growth which will come from mismanagement of policy maker: These factors are the different in international culture among countries, and the global warming and natural disaster from the excess consumption and excess production. These selfish, competition and economic greedy of people will lead to economic, social, and natural disaster problems. To reduce the socioeconomic disadvantages and global disaster, board's committee, and Co-ops manager as well as chief executive officer (CEO) of the IOFs must have a good understanding on these five similarities factors. Appropriate management of these five similarities factors will lead the firms to reach their high managerial efficiency, customer value, firm value, and finally economic growth.
\end{abstract}

Keywords: Co-operatives, investor owned firms (IOFs), economic growth, not-for-profit firms, general national factors, market industry factor, five forces, value chain

\section{Introduction}

It was accepted worldwide that the world economic real growth rate had a trend to reduce gradually, according to the instability in the growth rate of both gross domestic product (GDP) and gross national product (GNP). In addition, the economic growth was subtracted by the natural disaster and socioeconomic problem.

In order to stimulate economic growth of a country, the policy maker must have a good understanding on

Chanchai Petchprapunkul, Ph.D., senior lecturer, Department of Cooperatives, Faculty of Economics, Kasetsart University, Bangkok, Thailand.

Correspondence concerning this article should be addressed to Chanchai Petchprapunkul, Faculty of Economics, Department of Cooperatives, Kasetsart University, Bangkaen Campus, Bangkok 10900, Thailand. E-mail: fecochpe@ku.ac.th. 
what the engines for the economic growth are. One giant mechanism is the higher productivities in the supply side of the whole economy. In the same time, this mechanism was down-sized by many negative trickles down multiplier effects. The way to increase and maintain the real growth rate is to pursue the better economic growth concept that is the sustainable growth to create green and constructive economy.

Not only the investor owned firms (IOFs), but also the co-op business performance is encouraging the growth of the economy. In the year 2012, the United Nation (UN) proclaimed that the philosophy of the cooperative business organization and the way of Co-ops business operation can be promoted to assist the world economy. Co-op business organization had a philosophy to cooperate together to create growth with stability. The goal of the Co-op organization is not looking for profit but only surplus. They allocated all surpluses to their members. Thus, their member can have higher quality of life, lower income inequality, and higher welfare. Since the firm itself has not looked for business benefit, the firm has no risk burden. But, in the same time, most of the Co-ops, especially in the developing country are small and have a narrow business volume to help their member and have only small effects on their member's way of life. The best way to stimulate the real economic growth is to blend the advantage of these two kinds of the firms into one marked to get both of the benefit of the two business philosophy.

\section{Research Objective}

The research objectives are as follows:

- to elaborate that though the Co-ops and the IOF had the difference in their goal and objective of the business philosophy, the cooperation between the Co-ops business organization and its management and the IOF business organization and its management together will create the real and sustainable economic growth rate;

- to identify that the five different factors between the co-ops and the IOF are: organizational structure, goal, and objective; ownership advantage and financing policy; investment policy; dividend payout policy; and social and mutual aspect;

- to indicate that the five similarities factors between the co-ops and the IOF are: general national variables; market and industry variables; entrepreneurial opportunity or threat; entrepreneurial capacity: strength/weakness; and business or firm dynamic-active: sale, profit and lost

\section{Theoretical Concepts and Conceptual Framework}

There are 10 measurements: Five of them are similarities factors and five of them are different factors between the Co-ops firms and the IOF firms.

\section{Five Different Factors}

Different in organizational goal, objective, and structure. (1) Organizational goal and objective. Cooperative goal is that a not-for-profit (NFP) (Cobia, 1989; Petchprapunkul, 2006) organization has its business objective to service their members, while the IOF goal is that the general capitalism looks for the profit maximization (PM). The former therefore did everything for their member benefit not their organization, but the latter did everything for their share holder wealth.

(2) Organizational structure. Co-op organizational structure is composed of their general members and the whole member elected a group of 15 members to be the board of director. One in the 15 will be chairman, the leader of the board committee. Board committee will hire some professional managers to be the Co-ops 
manager, staff, and workers. Policy of the Co-ops mostly came from their annual general meeting. But the IOF structure is composed of the share holder, executive board, and management.

Different in ownership advantage and financing policy. Co-ops share or stock is owned by their member, called "member owner" principle controlled by their member or "member control" principle distributing benefit to their member or "member benefit" principle (Cobia, 1989). The business ownership within the Co-ops firms is owned by their members and administered by their elected board of member who manage their businesses through the management team, but the ownership within the IOF is owned by the share holders and managed by their executive officer hired by the company.

Different in the investment policy. The Co-op organization mostly has its investment policy to provide service to their member, but the IOF investment policy is to find profit for the share owner. The investment policy of the Co-op depends on the needs of their membership and the members' economic and social problem. For the IOF, their investment policy depends on the profit margin and the rate of return they can generate from their cash inflow and income stream, which have to exceed their cost of financing.

Different in dividend payout policy. The board member of the cooperative at the year will allocate their surplus to their member in the form of patronage refund and dividend payout as much as possible. But the IOF firm will pay their profit to their share holder in the form of money return, according to the number of share or stock they held. The Co-ops will not accumulate their surplus to their own organization but to their member, because their investment is all for their member benefit, while the IOF is doing everything for the share holder wealth.

Different in the social and mutual aspect. Co-op firm looks for member surplus and welfare, while the IOF looks for the share holder wealth. The Co-op firm is always looking for the mutual aspect to reduce their selfish. They are globally increasing their important role in local, regional, national, and international socioeconomic development. But the IOF mostly looks for its own sides. They do not care the socialism but mostly are concentrated on a perspective of the individualism, not collectivism.

All these five different factors are the measurement of why or how the Co-op was established and why and how the IOF was established. These five different factors need five different approaches to identify and pursue their business to reach the organizational goal or effectiveness. But from the past up to present, many weak points to the economy can be seen, especially the income inequality and turbulence to the society and citizen. Many of the policy makers in many countries in the world, not only the developed countries, but also the developing countries, had made these mistakes. This is the most serious issue. The world had faced many problems, both the nature and the socioeconomic ones, for examples, the global warming, the natural disaster, over consumption of natural resource and excess consumption of economic resource, the inequality of income distribution, and so on.

However, it still has five more similarity factors for the policy maker to blend and synthesize their business managerial approach, to create their efficiency, to make their internal function meet their sale, revenue, cost, profit, and lost.

\section{Five Similarities Factors}

It is the time to relocate misunderstanding and mis-policy management to turn the next decade into one marked out by much faster and more sustainable growth of the corporation between the Co-op models and IOF model to promote and carefully support the economic growth of every country. The solution is related to the 
adjustment of the five similarities mechanism of the engine of these two kinds of firms.

General national factors: S-P-E-L-T. These general national framework conditions are what and how to scan the general environment in five dimensions: $\mathrm{S}=$ social, $\mathrm{P}=$ political, $\mathrm{E}=$ economic, $\mathrm{L}=$ legal, and $\mathrm{T}=$ technology.

Aguilar (1967) proposed a concept of PEST and this concept had been added with one more L ( $\mathrm{L}=$ legal). Anyway, the policy maker has to scan these five dimensions to evaluate that the existing environment have created or generated any opportunities or threats to the organizations. The general national factors: S-P-E-L-T are as follows:

- Social openness;

- political/government policy;

- economic and financial condition;

- legal condition;

- technology, Research \& Development (R\&D).

If the environment of these all five factor created an opportunity to the firm, it's the time to penetrate the business into the market to gain the market share. The next step is to look for and assess what will penetrate to the new market with the existing product or the new product (Ansoft, 1965).

Market and industry factors. Porter $(1979,1980)$ suggested a "five forces" model: He explained that every firm has to evaluate the density of the rivalry in the industry or the market structure when doing business. This concept is to calculate the competitive advantage level, which will be based on the other four independent variables: firstly, the new entry which will come into the industry with the excess supply to the industry; secondly, the substitute product, whether the product would be replaced by the future substitute goods or services, the market will be lost; the third and fourth variables are the bargaining power of supplier and buyer, which will reduce the market share or create the higher cost of production. As competitive advantages, five forces model are:

- rivalry in the industry;

- new entry;

- substitute product;

- bargaining power of supplier;

- bargaining power of buyer.

Co-op/IOF business opportunity-threat. According to those two external factors: spelt and five forces which the firms can not adjust or change them, the firms can only evaluate whether those external factors have created opportunity or threat to the firm or not. Therefore, the firm has to scan their internal factor, to find out that his firm has any strength or weakness to pursue his business policy and plan, to be market leader, and to gain market share (Ansoft, 1965).

Co-op/IOF strength/weakness. This is the step of scanning the firm internal functions or structure that has any positive or benefit or advantage over the competitors. If it has no any strengths, but weakness, it has to prepare to prevent, protect, or adjust the business process as early as possible. The overall business process of a firm has included overall activities which will create value chain to the firm and its customer. Therefore, the management has to explore the strength or weakness in all of the functions.

Business/firm dynamic-active (sale, profit/lost). Porter (1985) suggested that a firm must have to create its value chain to both the firm and customer. Every firm has two parts of activities. The first one is the primary 
activities and the second one is the secondary activities. Primary activities consisted of three parts. The first part is the product interrelationship, the second part is marketing and sales, and the third part is service. Product interrelationship is compost of inbound logistic, operation, out-bound logistics. Secondary activities are composted of firm infrastructure, human resource management, technology development, and procurement.

Economic growth of a country. According to the measurement models, if a firm can manage, get, and maintain the overall strength, it will reach the profit margin. Finally, this profit margin is both the Co-op and the IOF surplus or profit respectively. At the same time, the growth of business sector will lead to demand for labor or employment and economic growth from the supply side.

If policy makers of these two kinds of firms have a good understanding on both the differences and similarities factors, by blending up them together, all these factors will generate the sustainable economic growth to every country.

Business life cycle theory: Population ecology, resource dependence, institutionalism theory. How those of firms can survive in the business arena depends on their competence and capability adapted in the business and industry. According to the "population ecology" theory (Freeman \& Hannan, 1977), if the firms cannot adapt them, they will be dead after a short period of establishment or bird stage. After that, they have to try to find access to some resources. According to the "resource dependent" theory, every firm has access to some resource spent in their business and functions. If the firm can find the needed resources, they will then expand their business, but if they cannot access to the needed resources, they will go to the contraction stage or even the dead stage.

(1) Business at the birth stage: At this stage, the policy maker has to know or need to know that the firm which will can survive in the industry must have and adjust its organization like an human being, the firm which cannot adjust to the environment will not give a birth to itself in such market. This belongs to the "population ecology" theory.

(2) Business at the stage of expansion: At this stage, the firm has to acquire resources such as capital for investment and expand the market. If the firm cannot find the resources, they cannot be the market leader or even challenger. This is the suggestion from the "resource dependence" theory.

Lastly, every firm has to know about the institutional theory, which explained that a well-systematic firm has to challenge, adopt, or imitate the big firm to make themselves professionally as the general perfect institution.

\section{Research Model}

The researcher adopted the similarities factor together and constructed a research model as posited in Figure 1. It can be elaborated that the successful Co-op and IOF performance will influence the economic growth of a country depending on two groups of factors: The first group is the level of understanding on the different structure, goal, objective; investment policy; dividend payout policy; and the social and mutual aspect, which has to be managed as efficient as possible, matching the organizational goal and objective of the Co-op and IOF case by case.

The second group of the variable is the management factors, as elaborated in the research model, if the policy leader pertains their competence and can organize the five independent variables to explain the dependent variable. The research model elaborated the structural equation modeling: SEM, which consists of only one structural model and six measurement models. The structural model explained the five independent measurement models and finally the economic growth of a country. 


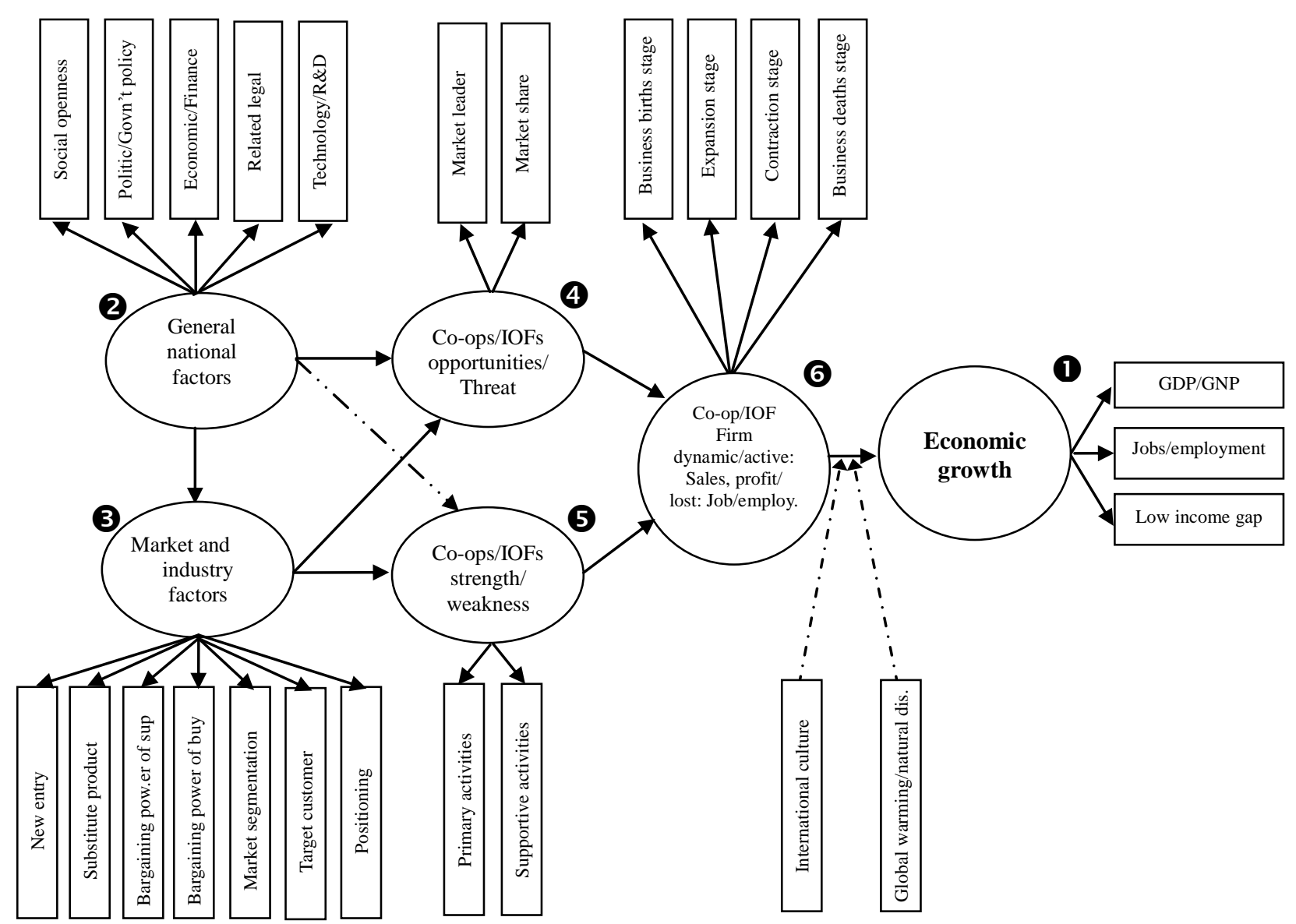

Figure 1. Factors determine the Co-ops business performance and the IOFs business performance to economic growth.

\section{Dependent Variable}

In this study, the dependent variable measurement (economic growth) has totally three sub-measurements: the GDP, jobs/employment, and low income gap. These mean that the all independent variables composed together can explain the high level of GDP, explain high level of job employment, and create low income inequality.

\section{Independent Variables}

Independent variables are shown as follows:

- General national factors;

- Market/industry factors: five forces (Porter, 1980) and STP-marketing (Borden, 1964);

- Co-ops/IOFs business opportunities and threat;

- Co-ops/IOFs business strength and weakness;

- Co-ops/IOFs business dynamic-active (sales, profit, and lost).

\section{Intervening Variable}

In the model, they are also the intervening variables, which will change the relationship between the dependent variable and the independent variables as the following:

- International culture;

- Global warming/natural disaster. 


\section{Research Methodology}

This study employed the Delphi Technique which is a systematic forecasting method involving structured interaction among group of experts on a subject (Caplan, 1950). Delphi Technique typically includes at least two rounds of experts answering questions and giving justification, providing the opportunity between rounds for changes and revisions. The multiple rounds, which are stopped after a pre-defined criterion is reached, enable the group of experts to arrive at a consensus forecast on the subject being discussed.

According to the literature review, the researcher had constructed an open-end questionnaire to ask for the expert opinion on what should be the major factors contributed from Co-ops and IOFs performance to create the economic growth.

\section{Conclusions}

According to the results from the first round survey, the overall 25 factors are gained. These 25 factors were observed and classified into the six latent variables. These six latent variables match the co-operatives theory and the IOFs theories as well (Table 1).

Table 1

Dependent and Independent Variables

\begin{tabular}{|c|c|}
\hline Latent dependent variables with its measurement & Independent variables with its measurement or observe variables \\
\hline Economic growth (GNP/GDP, job employ, income gap) & Firm dynamic/active: (1) sales; (2) profit/lost; (3) job employment \\
\hline \multirow{2}{*}{$\begin{array}{l}\text { Co-ops/IOFs, firm dynamic/active: sales, profit/lost, job } \\
\text { employment (within four stages of business lifecycle) }\end{array}$} & Co-ops and IOFs' business opportunities/threat \\
\hline & Co-ops and IOFs' organizational strength/weakness \\
\hline \multirow{2}{*}{ Co-ops and IOFs' business opportunities/threat } & General national factor "S-P-E-L-T analysis factors" \\
\hline & Market and industry factor: (1) Five forces; (2) STP-marketing \\
\hline \multirow[b]{2}{*}{ Co-ops and IOFs organizational strength/weakness } & Market and industry factor: (1) Five forces; (2) STP-marketing \\
\hline & $\begin{array}{l}\text { Firm specific factors: (1) primary activities: inbound/operation/out } \\
\text { bound; marketing-sales-service. (2) supportive activities: infra } \\
\text { structure; technology; HRM; procurement }\end{array}$ \\
\hline
\end{tabular}

Apart from the first round, the researcher had contacted back again to the 33 persons who are the 11 lecturers in the area of cooperative economics, 11 doctoral international students, and 11 policy makers in the Ministry of Agriculture and Co-operatives. This second round of survey comes up with the output of the study. All of 33 respondents as posited in Table 2 reported that the overall 25 measurements influence both the performance of Co-ops and IOFs firms.

Table 2

Types and Number of Respondents

\begin{tabular}{lll}
\hline Types & Number & $\%$ \\
\hline Lecturer in the universities & 11 & 33.33 \\
Doctoral international students & 11 & 33.33 \\
Policy maker & 11 & 33.33 \\
Sum total & 33 & $\approx 100.00$ \\
\hline
\end{tabular}

Even Co-ops are the social enterprise, they are different from the IOFs only in their goal, objective, structure, and the way to do business. However, both of them were affected by the business factors. 


\section{References}

Ansoft, I. (1965). Corporate strategy. Pittsburgh: Carnegie-Mellon University Press.

Caplan, D. (1950). Delphi method, operation research. Santa Monica: Rand Corperation.

Cobia, D. (1989). Cooperatives in agriculture. Englewood Cliffs: Prentice Hall.

Aguilar, F. J. (1967). PEST analysis: Scanning the business environment. NewYork: Macmillan Publishers Ltd.

Freeman, J., \& Hannan, M. (1977). Population ecology theory. American Journal of Sociology, 82(5), 929-964.

Porter, M. E. (1980). Competitive strategy: Techniques for analyzing industries and competitors. New York: Free Press

Porter, M. E. (1985). The competitive advantage: Creating and sustaining superior performance. New York: Free Press.

Porter, M. E. (1979). How competitive force shape strategy. Retrieved from http://www.docin.com/p-291884535.html

Borden, N. H. (1964) The concept of the marketing mix. Journal of Advertising Research, 4, 2-7.

Petchprapunkul, C. (2006). Performance of agricultural marketing cooperatives in Thailand. Saarbrücken: Lambert Academic Publishing. 